\title{
TRANSPORT DISADVANTAGE AND EVENING OUTINGS: THE EXAMPLE OF HIGH SCHOOL STUDENTS OF THE CITY OF ZAGREB
}

\author{
Slaven Gašparović ${ }^{1}$ \\ ${ }^{1}$ Department of Geography, Faculty of Science, University of Zagreb, Marulićev trg 19/II, Croatia
}

Received 25 May 2017; accepted 29 June 2017

\begin{abstract}
This paper discusses the issue of transport disadvantage, which can influence people's everyday lives. Evening outings are very important part of young people's lives. Since young people are considered transport disadvantaged part of society, the aim of this paper is to investigate the impact of transport disadvantage on evening outings of high school students of the City of Zagreb. Particular emphasis is put on the difficulties in accessibility of evening outings and the way transport influences them. The research was based on quantitative, as well as qualitative methods. Quantitative data were obtained through questionnaire performed among 826 high school students of high schools of the City of Zagreb. Qualitative data were collected through eight focus groups, in order to deepen the research. Data analysis revealed that almost 3/4 of high school students expressed the attitude of having difficulties with accessibility of evening outings. It also revealed that almost $3 / 4$ of the students who participated in the evening outings outside their neighbourhoods stated that transport influenced the activity. The existence of students who cannot attend evening outings because of transportation was also determined.
\end{abstract}

Keywords: transport disadvantage, high school students, evening outings, City of Zagreb.

\section{Introduction}

One of the most important factors in human life is transportation. It impacts the access to all life functions and their performance. Hereby, mobility and accessibility have an important role as the fundamental requirements of today's society (Hoyle and Knowles, 1998). Some situations may jeopardize the use of transport services and the fulfilment of daily needs, as the result of limited or impossible mobility and accessibility. If individuals or entire social groups find themselves in such a situation, they will be exposed to the process of transport disadvantage (Yigitcanlar et al., 2010; Rosier and McDonald, 2011; Gašparović, 2016). Some authors have defined a range of groups being transport disadvantaged. One of these groups are children and youth (e.g., Murray and Davis, 2001; Stanley and Stanley, 2004; Dodson, et al., 2004; Hurni, 2006; Hurni, 2007). Though some authors consider them transport disadvantaged, it should be emphasized that high school students from the ages of 15 to 18 years are considered the most exposed to transport disadvantage. Smaller and elementary school aged children have a lesser need for mobility than high school students. High school students require to travel a greater distance to their activities

${ }^{1}$ Corresponding author: slaveng@geog.pmf.hr 
(i.e. school, extracurricular activities, evening outings) than younger children (Fyhri and Hjorthol, 2009; Hopkins, 2010; Horton, et al., 2011). For this reason, the social group considered in this paper is the group of high school students.

Evening outings are an integral part of many young people's lives. They cover a whole range of different cultural styles, identities, experiences and places of their development. Places where evening outings take place include different locations, such as bars, disco clubs, cafes as well as parks, streets, private parties, concerts etc. Studying and understanding the evening outings of young people is further complicated by certain features which affect their identity such as gender, age, race, nationality, living location, sexual orientation, etc. The locations of evening outings is mostly related to urban areas where their accommodation in the city depends on a range of economic, constructional, legal, social and other factors (Chatterton and Hollands, 2003).

Many young people have to travel to the locations of evening outing. Considering the time of traveling and its purpose, some important elements will be revealed during travel such as travel time, safety in transport, and the like. Thus, this segment will represent fruitful topics for study, especially considering the fact that high school students are largely engaged in evening outings while being transport disadvantaged, indicating that they will depend on the organization and use of public transport, parents and friends, and taxi. In addition, certain differences will exist between traveling to the place of evening outing and returning home as these can represent two relatively different parts of the day (i.e. night).
This paper will investigate the impact of transport disadvantage on evening outings of high school students. The evening outings that students realize outside their neighbourhood will be considered. The reason for this is the journey that students have to take if they go out in the evening, being in contrast to outgoings within the neighbourhoods where walking is good option due to the relatively small distance (this is confirmed in the questionnaire pre-testing). In addition, The Family Law (Official Gazette 116/03) restricts young people under 16 to go out at night alone and they must be accompanied by a parent or other adult parent trusted person, while after their 16th birthday they may go out at night without restrictions.

Few papers have examined the issue of transport disadvantage of young people, and especially the relationship between evening outings and transport disadvantage. This is also the motive behind this work. A series of papers deals with the issue of evening outings of young people, whereby transport is researched in terms of the impact of alcohol consumption on the safety of young people's travel, especially on car use (e.g. Calafat et al., 2009; Scagnolari et al., 2015; Houwing and Twisk, 2015).

Still, some papers deal with the problems young people have when traveling at night for evening outings thereby addressing indirectly transport disadvantage. Thus, the survey conducted by the Department for Transport in the United Kingdom showed that girls show greater fear of traveling at night than boys. Additionally, this study points at the common problem of lack of public transport by periurban and rural areas, so people usually have to use the taxi, 
which means an additional expense (House of Commons, 2013). The problems of young people with night public transport in the periurban and rural areas are also present in Australia, where the greatest problem is very low frequency or even lack of public transport, so young people are often forced to hitchhike or walk which affects their safety (Currie et al., 2005). Similar results from the United Kingdom are presented by Bourn (2013), who points at the problems of young people with night public transport due to cutting funding costs. The feeling of being safe is an important aspect in the life of high school students of the City of Zagreb, with particular emphasis on the importance of security in public transport at night (Gašparović and Jakovčić, 2014). Similar results were obtained from Currie et al. (2013), whose research showed that over 40 percent of surveyed youth felt unsafe or very unsafe using public transport at night in Melbourne. Young people from Melbourne's periurban area describe more problems in traveling at evening outings than young people from the inner city. Problems were frequency of bus and train, as well as difficulties in finding a taxi, while young people from the inner city for traveling at night mainly use bicycles, trams or pedestrians (Duff and More, 2015).

\section{Methodology}

The basics of this paper were the methods of surveying and interviewing. The survey was conducted in seven high schools of the City of Zagreb. A total of 1053 students were surveyed, which is about $3 \%$ of the total number of high school students in the City of Zagreb. After the questionnaires were processed, 826 students remained (only students living in the City of Zagreb and without a driver's license were taken into consideration). The survey took about 30 minutes. Survey included, among other issues, participants' general information, as well as attitudes and opinions about the evening outings. Thus, students were surveyed about the difficulties with accessibility of evening outings out of their neighbourhood. They were also surveyed about the impact of transport on the evening outings (about impact's strength, frequencies and ways of influence) as well as about the problems they could possibly met due to transport when going out at night. The transport mode used by students as well as the estimated time (in minutes) required to travel from home to the location of evening outing and vice versa were also surveyed. Regarding the gender ratio in the survey, there were 429 females (51.9\%) and 397 males (48.1\%).

Before the main survey, a pre-test was performed to test the theoretical and empirical validity, reliability and applicability of the questions in the main questionnaire according to the recommendations suggested by Cohen et al. (2007).

In order to obtain more in-depth information, the research also included an examination using a focus group method. The focus groups were conducted in two high schools in the City of Zagreb, where students were divided into eight groups (four per each school) based on their age and gender (each group was comprised of 8 to 10 students.). Group I included female students of the 1st and 2nd grades, Group 
II male students of the 1st and 2nd grades, Group III female students of the 3rd and 4th grades, and Group IV male students of the $3 \mathrm{rd}$ and 4 th grades. Within each group, there was an evident dichotomy among the students with regard to their living location (half of the students lived near the city centre and half lived nearer to the city periphery). Focus groups research was performed using the audio technique (voice recorder). The whole conversation with a particular group was recorded and then transcribed.

In conducting the research, the Code of Ethics of Research with Children (2003) was fully abided by, because ethic issues are important segment in the research when youth are included (Cohen et al., 2007). A permit for the research was obtained from the Ministry of Science, Education and Sport of the Republic of Croatia and from the principal of each school. Consent for interviewing students was also provided from the students' parents. The survey questionnaire was anonymous and voluntary.

The data collected in the survey were processed using the software package SPSS Statistics 20.0 using the statistical correlation method (Pearson and Spearman correlation coefficient) and other simple mathematical operations. Spatial analysis was performed using the Geographic Information System (GIS) tool. The ArcInfo 10 software was used. As a basis for spatial analysis, data from the questionnaire was used, most preferably the address of the student. Spatial coordinates of student addresses are taken from the "Digital Orthophoto Layer 2012"
(DOF, 2012) of the GeoPortal of the 'Zagreb Spatial Data Infrastructure" (City of Zagreb, 2012).

\section{Results and Discussion}

As evening outings are part of the students' free time and due to different objective and subjective reasons, not all children participate in evening outings. The survey found that this activity was practiced more or less regularly by 714 students (of 826 respondents), which indicated the great importance of this segment in lives of high school students.

When traveling to the venue of evening outing, the main characteristic was greater usage of public transport and, to a lesser extent driving by somebody else (although the student had the ability to travel by public transport) or taxi (for convenience and simplicity) (Table 1). These relationships changed considerably regarding the return to home after the evening outing. Students still used public transport, but because of its organization during night and safety and other subjective and objective factors, the use of car or taxi increased considerably in those students who did not have the opportunity to travel by public transport (e.g. does not operate at an acceptable distance from their place of residence). Because of the night regime of public transport, taxis (for its convenience and simplicity) or car (someone else was driving the students, even though they had the possibility to travel by public transport) were used more. These travel needs had direct consequences on the problems that students encounter. 
Table 1

Travel Needs of High School Population in the City of Zagreb

\begin{tabular}{|l|l|l|l|l|}
\hline \multirow{2}{*}{ Transport mode } & \multicolumn{3}{l|}{ Evening outing outside their neighbourhoods } \\
\cline { 2 - 5 } & Going out & \multicolumn{2}{l|}{ Returning home } \\
\cline { 2 - 5 } & Number & Share (in \%) & Number & Share (in \%) \\
\hline On foot, by bicycle & 27 & 3.8 & 33 & 4.6 \\
\hline Taxi due to comfort and simplicity & 69 & 117 & 16.4 \\
\hline $\begin{array}{l}\text { Car, though they have the possibility of } \\
\text { using public transport }\end{array}$ & 86 & 12.0 & 93 & 13.0 \\
\hline Public transport & 513 & 71.8 & 261 & 36.6 \\
\hline $\begin{array}{l}\text { Car or taxi because they had no possibility } \\
\text { of using public transport }\end{array}$ & 19 & 2.7 & 208 & 29.1 \\
\hline Some other way & - & - & 2 & $\mathrm{~N}=714$ \\
\hline
\end{tabular}

Source: Survey

Out of 714 students, almost $3 / 4$ of students (73.9\% or 528 ) expressed the attitude that they had transport-based difficulties with the accessibility of evening outings. It is interesting to note that students who walked or used a bicycle to participate in the evening outings stated to have less problems with the accessibility of evening outings (Table 2 , Table 3). All other shares were relatively high. Thus, all students (100\%) who used taxi or car (i.e. driven by parents or other person) to reach the evening outings venues because they did not have possibility of using public transportation, expressed the attitude that they had problems with the accessibility of evening outings due to transportation. In this category almost all students (98.1\%) stated to have problems in the segment of returning home from the evening outings. Nearly $80 \%$ (79.9\%) of students traveling to the venue of the evening outing by public transport, and just over $70 \%$ (70.1\%) when returning home by public transport, stated to have difficulties with accessibility evening outings due to transportation, respectively. Surprisingly, many students that used a taxi or someone else was driving them stated to have difficulties even if public transport was available. Obviously, the cost of taxi, the waiting time and the organization of transport by parents or friend overcame the benefit of using these modes of transport.

\section{Table 2}

Findings Related to Travelling to the Venue of Evening Outing

\begin{tabular}{|l|l|l|l|}
\hline Transport mode & $\begin{array}{l}\text { Number of students } \\
\text { participating in } \\
\text { evening outings } \\
\text { outside of their } \\
\text { neighbourhoods }\end{array}$ & $\begin{array}{l}\text { Number of students } \\
\text { encountered difficulties } \\
\text { with accessibility of } \\
\text { evening outings outside of } \\
\text { their neighbourhoods }\end{array}$ & Share (in \%) \\
\hline On foot, by bicycle & 27 & 1 & 3.7 \\
\hline Taxi due to comfort and simplicity & 69 & 50 & 72.5 \\
\hline $\begin{array}{l}\text { By car, though they have the } \\
\text { possibility of using public transport }\end{array}$ & 86 & 48 & 55.8 \\
\hline Public transport & 513 & 410 & 79.9 \\
\hline $\begin{array}{l}\text { Car or taxi because they have no } \\
\text { possibility of using public transport }\end{array}$ & 19 & 19 & 100 \\
\hline Some other way & 0 & 0 & 0 \\
\hline Total & 714 & 528 & 73.9 \\
\hline
\end{tabular}

Source: Survey 
Table 3

Findings Related to Travelling to Home

\begin{tabular}{|l|l|l|l|}
\hline Transport mode & $\begin{array}{l}\text { Number of students } \\
\text { participating in } \\
\text { evening outings } \\
\text { outside of their } \\
\text { neighbourhoods }\end{array}$ & $\begin{array}{l}\text { Number of students } \\
\text { encountered difficulties } \\
\text { with accessibility of } \\
\text { evening outings outside of } \\
\text { their neighbourhoods }\end{array}$ & Share (in \%) \\
\hline On foot, by bicycle & 33 & 7 & 21.2 \\
\hline Taxi due to comfort and simplicity & 117 & 79 & 67.5 \\
\hline $\begin{array}{l}\text { By car, though they have the } \\
\text { possibility of using public transport }\end{array}$ & 93 & 53 & 57.0 \\
\hline Public transport & 261 & 183 & 70.1 \\
\hline $\begin{array}{l}\text { Car or taxi because they have no } \\
\text { possibility of using public transport }\end{array}$ & 208 & 204 & 98.1 \\
\hline Some other way & 2 & 2 & 100 \\
\hline Total & 714 & 528 & 73.9 \\
\hline
\end{tabular}

Source: Survey

Clearly, problems in evening outings can arise due to the accessibility, which is dictated by the travel time distance from student's residence location to the location of his/her activity. For this reason, analysis was performed in regards to students who expressed the existence of problems with the accessibility of evening outings (Variables related to the attitude on the existence of transport based problems with the accessibility of specific activities are coded as follows: 1 - Yes, almost always (couple of times per week); 2 - Yes, often (once to twice per week); 3 - Sometimes (couple of times per month); 4 - Rarely (couple of times per year); 5 - Never). The result indicated a slight, though statistically significant correlation between the attitude of experiencing problems with the accessibility of evening outings and the travel time to them ( $\rho=$ $-0.174 ; p<0.01)$. Similarly, there was statistically significant correlation between the attitude of experiencing problems with the accessibility of evening outings and returning home $(\rho=-0.105 ; p<0.05)$. A slight, statistically significant association was present, although it appeared systematically and could suggest that students traveling longer to the venue of evening outing and from the venue of the evening outing to home more often encountered transport-based problems with the accessibility of evening outings. This raised the possibility that there may be a problem affecting the distance of evening outings to their accessibility.

The existence of transport-based problems with the accessibility of evening outings was just one of the segments in the study of the impact of transport disadvantage on evening outings of students. In order to gain a more detailed insight into the issue, it was necessary to investigate the impact of transport on evening outings as transport may had an impact on a particular activity (Table 4). Almost 3/4 of the students (74.9 $\%)$ who participated in the evening outings outside their neighbourhoods stated that transport affected the activity. This fact was in accordance with the proportion of students who had transport-based difficulties with the accessibility of evening outings. Previously mentioned need to travel to the venues of the evening outings combined 
with night transportation and the potential problems associated with its use were obviously the main reasons for such a high share. Nevertheless, the majority of students $(55.7 \%)$ believed that transport rarely or occasionally impacts evening outings, with a poor or moderate influence. Still, $44.3 \%$ of students claim that transport often or almost always influenced their evening outings, with high or very high influence.

\section{Table 4}

Frequency and Strength of the Influence of Transport on the Evening Outings of High School Students

\begin{tabular}{|c|c|c|}
\hline Frequency/strength of the influence & Number of students & Share (in \%) \\
\hline INFLUENCE & 535 & 74.9 \\
\hline rare / poor & 100 & 18.7 \\
\hline occasionally / moderate & 198 & 37.0 \\
\hline often / high & 152 & 28.4 \\
\hline almost always / very high & 85 & 15.9 \\
\hline NO INFLUENCE & 179 & 25.1 \\
\hline TOTAL & 714 & 100 \\
\hline
\end{tabular}

Source: Survey

It has already been pointed out that the distance from some activity may have an impact on the activity itself. Within this context, the relationship between the travel time to and from the location of the student's evening outing and their attitudes about the impact of transport on this activity was analysed (Variables relating to the assessment of the frequency of influence of transport on specific activities are coded as follows: 1 - No influence; 2 - Poor influence / rarely influences; 3 - Moderate influence / occasionally influences; 4 - High influence / often influences; 5 - Very high influence / almost always influences). The results obtained showed the existence of correlation between the mentioned variables. In this context, it can be seen the way how the frequency of impact of transport on evening outings increased in students' opinion with regard to the travel time needed to go to these activities. Students who spent more time traveling to the venue of the evening outing claimed that transport more often and more stronger influenced evening outings compared with students who spent less time traveling to these activities. Regardless of whether it was a trip to the venue of evening outing $(\rho=0.218$; $\mathrm{p}<0.01$ ) or from the venue of the evening to the home $(\rho=0.101, \mathrm{p}<0.05)$, it was a slight statistical significance correlation. It pointed to the possibility of influencing of the distance on everyday life of an individual in a negative context. This implied that the result could also be interpreted as an assumption that students who travel longer to the location of evening outings had more problems with attendance than the students living closer to the venue of the evening outing.

If ind the biggest problem in the fact that the last bus leaves at 12 (midnight), and the first starts at half past 5, and I don't have tram which goes by my place, so I have to use taxi, or one of my parents picks me up.

[How much is the taxi?]

Taxi is $50 \mathrm{HRK}$ from the last tram stop to my home. Or, I have to leave an hour earlier than the others in order to catch the last bus.

(female student, 16 years, Botinec) 
So, I have to use tram and bus, but the last bus leaves at midnight, and then I have to take the night tram line to Dubec, and then walk $1.5 \mathrm{~km}$ by foot. And if this is the case, I need hour and 20 minutes to get home, which is very long. I wish I had a car... (male student, 16 years, Branovečina)

I have to leave earlier than the ones who live closer because it takes long time to get home.

(male student, 15 years, Vinogradi)

I live in the Upper town (Gornji grad) and the problem is that the most of the clubs are in Jarun, which is far.

(male student, 17 years, Gornji grad)

Students living relatively close to the venue of the evening outing or have relatively well transport connections did not feel any bigger problem with the transport at evening outings. A new situation occurred where students, from neighbourhoods located further from school or extracurricular activities, were in a better position to travel to evening outings. Students living in neighbourhoods connected very well by the daily transport may be disadvantaged if their neighbourhood was not serviced by night public transport or if they lived far away from the venue of the evening outings.

I don't have a problem. I have buses 'till midnight, and after that I have night tram lines, so I'm perfect.

(male student, 16 years, Rudeš)

It's great, the night bus line for Velika Gorica goes through New Zagreb (Novi Zagreb) and it stops near my house. It all depends where you live in town.

(male student, 18 years, Sloboština)

For students who felt that transport affected evening outings, the reasons for the impact varied. In doing so, certain factors were more prominent (Table 5).

\section{Table 5}

Ways in which Transport Impacted the Evening Outings of Students

\begin{tabular}{|l|l|l|}
\hline Way of influence & Number of students & Share (in \%) \\
\hline Frequency of public transport & 369 & 69.0 \\
\hline Taxi (organization and price) & 48 & 9.0 \\
\hline Loss of time & 36 & 6.7 \\
\hline Late for an appointment & 33 & 6.2 \\
\hline Organization of public transport system & 14 & 2.5 \\
\hline Distance from the venue of evening outing & 10 & 1.9 \\
\hline Safety & 8 & 1.5 \\
\hline Parent's concern & 8 & 1.5 \\
\hline Crowds in public transport vehicles & 8 & 1.5 \\
\hline Traffic conditions & 1 & 0.2 \\
\hline Total & 535 & 100 \\
\hline
\end{tabular}

Source: Survey 
Over $2 / 3$ of students $(69 \%)$ considered that the frequency of public transport at night had the greatest impact on evening outings. This issue was mainly reflected in the segment of returning to home from the evening outing, as it was mostly after midnight when public transport operates at the night schedule (on average every hour).

The night tram line operates rarely, and then I need to catch the night bus from Ljubljanica, which also operates rarely so I wait very long for it. This is why I sleep over at one of my friend or my parents pick me up.

[Is this hard for them?]

No, they want it.

(male student, 18 years, Špansko)

The problem is to return home, I have to leave earlier 'cause trams are rare. (male student, 16 years, BorovjeŽitnjak)

Some students used a taxi for certain reasons. The reason was mainly due to the rare frequency of public transport or the fear for personal safety. Most students believed that the taxi was not too expensive, but for some students the price was still be a problem. In addition, the problem also in the difficulty of finding a free taxi for transport.

My last bus is at half past 11 (23:30) and if I stay longer, I take a taxi.

[How much does it cost?]

It costs $30 \mathrm{HRK}$, it is not a problem, but still, I need to pay.

(female student, 16 years, Gračani)

If there is no taxi, I go by foot until I get it, and it happens that I can't get it for hour or two. I hardly wait to pass the driver's test. (male student, 17 years, Gornji grad)

The trams are very rare after 1 , and when I get to Črnomerec at somewhat after midnight I don't have bus to go home, and then I use taxi and I share it with my friends. I would certainly use public transport more often, and in this why we have to pay for taxi. Well, it is not too expensive, but it would be better not to pay as much.

(male student, 16 years, Vrapče)

Some students also faced the problem of taxi drivers' relations towards them, particularly in the segment of personal safety. Primarily this was manifested to the girls.

It can happen that the taxi drivers are "too communicative"... My friend once took a taxi and the driver was way "too friendly"... and then she just payed and went off.

(female student, 16 years, Travno)

Since time is an essential element in people's lives, important issue for students was also spending time on the journey. Thus, $6.7 \%$ of students thought that they lost too much time on traveling within evening outing, and this problem was most evident when they were returning home.

I use night trams, but it takes almost one and a half to two hours to get from Jarun to Borongaj. It's when we get to the tram stop, and the time till the tram arrives, and then it goes through half of the city... (male student, 16 years, BorovjeŽitnjak)

Within the importance of time in people's lives, one aspect can also be the problem 
of delay that some students pointed out (6.2\%). This referred mainly to the delay to the appointment place due to the poor public transport frequency. In relation to the public transport frequency, the problem of the public transport organization can also be referred to, especially within the spatial distribution of transport lines $(2.5 \%)$. This was certainly a problem for students living in neighbourhoods where night public transport did not operate. The problem related to the public transport organization, its frequency and travel time was also the problem of distance from the venue of the evening outing (1.9\%) which could actually affect any student, depending on the distance from the venue of the evening outing.

It affects (transport) on the way back home because the buses run approximately until midnight and then I go on foot to Mihaljevac for half an hour or call my parents.

(male student, 16 years, Markuševec)

Sometimes you do not even feel going out when you think how much you need to go home.

(male student, 18 years, Špansko)

The trams are very rare in the evening. It says in the display that it'll come for 5 minutes and come for 20. Then Mom is afraid for me.

(male student, 16 years, Botinec)

It is interesting to point out that the most significant transport problems associated with evening outings to students were largely related to transport frequency, travel time, distance and the like. Only a relatively small percentage of students indicated the night time safety $(1.5 \%)$ and parental care for their children $(1.5 \%)$ as problems. Students pointed to the importance of safety issue and the problems they facing only when these issues were mentioned to them.

Just recently, me and my friend were going from the cinema and for the first time we took the tram late at night because it came. We got into that tram and saw that every other man was asleep and drunk. Really, I said never again It's not worth it, taxi is $50 \mathrm{HRK}, 25 \mathrm{HRK}$ each. There are really all kind of people, some young guys were yelling, they had evening outing... (female student, 18 years, Špansko)

I'm afraid of night trams because people in these trams are drunk, homeless and so. And one tram goes once every hour across the whole city. And therefore, I don't feel comfortable when I go out and I'm scared and my parents are scared too so I rather take a taxi and pay whatever it takes than going to that tram and wait for it.

(female student, 16 years, Gračani)

I've never used a night tram or bus because my parents always pick me up and when I ask them to take a taxi or come by myself, they always say they'd rather pick me up.

(female student, 16 years, Travno)

I go to Aquarius and I take taxi to get there because it takes long to walk from the tram station. When I return, my mom comes to pick me up, it's better that I go back safely 'cause who knows what could happen to me.

(female student, 16 years, Pantovčak)

We use a taxi or parents to come for us.

[Is it a problem for you to ask your parents to come and pick you up?]

For us it is not a problem to bother our parents because they offer to come for us. They're worried about us. And when we go by taxi we often share the costs so it is not so expensive. 
Of course, this is the case when friends are from the same neighbourhood or close.

(male student, 17 years, Centar)

Many high school students went to the evening outings outside their neighbourhoods, but there were also students who did not participate in this activity. Of the 826 students surveyed, 112 did not participate to the evening outings for different reasons. Among these students there were 7 students who did not participate in the evening outings due to transportation, being $6.3 \%$ of the total number of students who did not participate in evening outings outside their neighbourhoods, and $0.9 \%$ of the total number of surveyed students. Regardless of the number, their quality of life in this segment was disrupted, and being in this way markedly transport disadvantaged. The main reason for the inability to participate in the evening outings was the lack of transport, whether it was public transport, or transport in general (Table 6).

\section{Table 6}

Reasons for the Inability to Participate in the Evening Outings Outside the Neighbourhood due to Transport

\begin{tabular}{|l|l|l|}
\hline Reasons & Number of students & Share (in \%) \\
\hline Organization of public transport & 4 & 57.1 \\
\hline Lack of any kind of transport & 2 & 28.6 \\
\hline Safety & 1 & 14.3 \\
\hline Total & 7 & 100 \\
\hline
\end{tabular}

Source: Survey

Students generally complained about the public transport organization in the context of the lack of lines in the part of the city where they lived. Also, some students had a problem, not only with the lack of public transport, but also with transportation in general (possibly parents and friends could not help in transport). Only one student pointed to the problem of personal safety. The students' comments that follow in the text were not obtained through the focus groups as there were no students who did not go to the evening outings. Students' statements from the questionnaire are showed here.

Parents should pick me up in the town and I'm afraid to use a taxi.

(female student, 15 years, Lučko)

Not enough buses in the evening. (male student, 17 years, Grančari)
No transportation to get back.

(male student, 17 years, Adamovec)

I have no buses at night so I can't (participate at evening outing), and it is not worth to wait until 6 am or pay a $100 \mathrm{HRK}$ for taxi.

(male student, 16 years, Ježdovec)

I don't have night transportation.

(male student, 16 years, Graberje)

I have no transportation to get back home. (male student, 17 years, Markuševec/ Miroševec)

The trains do not operate after midnight, and by tram and bus it lasts too long. (female student, 17 years, Retkovec)

It is also necessary to analyse students' spatial distribution (Figure 1). Students 
who thought that transportation was the reason they could not participate in evening outings outside their neighbourhoods lived relatively far from the city centre. These were places that had elements themselves of being transport disadvantaged, or where public transport operated less frequently than in wider city centre, i.e. southern part of the City of Zagreb, sub mountainous area of Medvednica mountain and the western and the eastern part of the City.

Transport can affect social interactions of people (Cullinane and Stokes, 1998; SEU 2003, Currie and Stanley, 2007). It can be assumed that participation in some activities will increase the intensity of social interactions, and thus increase the number of friends. It is therefore necessary to investigate whether there is any influence of engagement in the evening outings on the student's social interaction and whether there is a difference between students who participated evening outings and the ones who did not participate because of transport. As a variable defining the intensity of social interaction, a number of good (or close) friends was taken. First of all, it was necessary to investigate the relationship between engagement to evening outings and the number of good friends. A slight but significant correlation between these two variables $(\mathrm{r}=-0.086, \mathrm{p}<0.05)$ (Variables related to (non)participating in evening outings outside the neighbourhood are coded as follows: 1 - Almost always (several times a week), 2 - Often (once or twice a week); 3 - Sometimes (several times a month); 4 - Rarely (several times a year); 5 - I do not participate in evening outings outside my neighbourhood) is observed. Such result lead to the assumption that the number of friends increased with the frequency of attending evening outings. All the students were taken into account in these analyses, meaning that the students not going out in the evening because of transport were also analysed, but also because they had everything needed for evening outings in their neighbourhood or of some other reasons. If only students engaged in the evening outings were taken into consideration, the statistically insignificant correlation between the two previously mentioned variables $(r=-0.057$; p > 0.05) was obtained. Regarding the average number of close friends, it was 7.5 for students who attend evening outings outside their neighbourhood, while in the case of students who not go to evening outing outside their neighbourhood due to transport it was 6.9. It should also be noted that 5 out of 7 students $(71.4 \%)$ not engaged in the evening outings outside their neighbourhood because of transport had fewer good friends than the average number of good friends of students engaged in the evening outings outside their neighbourhood. These data could point to the impact of transport on social interactions, but still, these data should be taken with the reserve since they may be the result of the survey sample and a very small number of students not participating in the evening outings outside their neighbourhood because of transport.

Here, the obtained sample of students not participating in the evening outings outside their neighbourhood because of transport was too small, thereby limiting the use of correlation analysis. They lived in the periphery of the City of Zagreb, so the aforementioned facts are a pledge for a potential future study of the impact of transport on evening outings in specific city neighbourhoods with special emphasis on the peripheral areas of the city. 
$\widehat{N}_{N}$

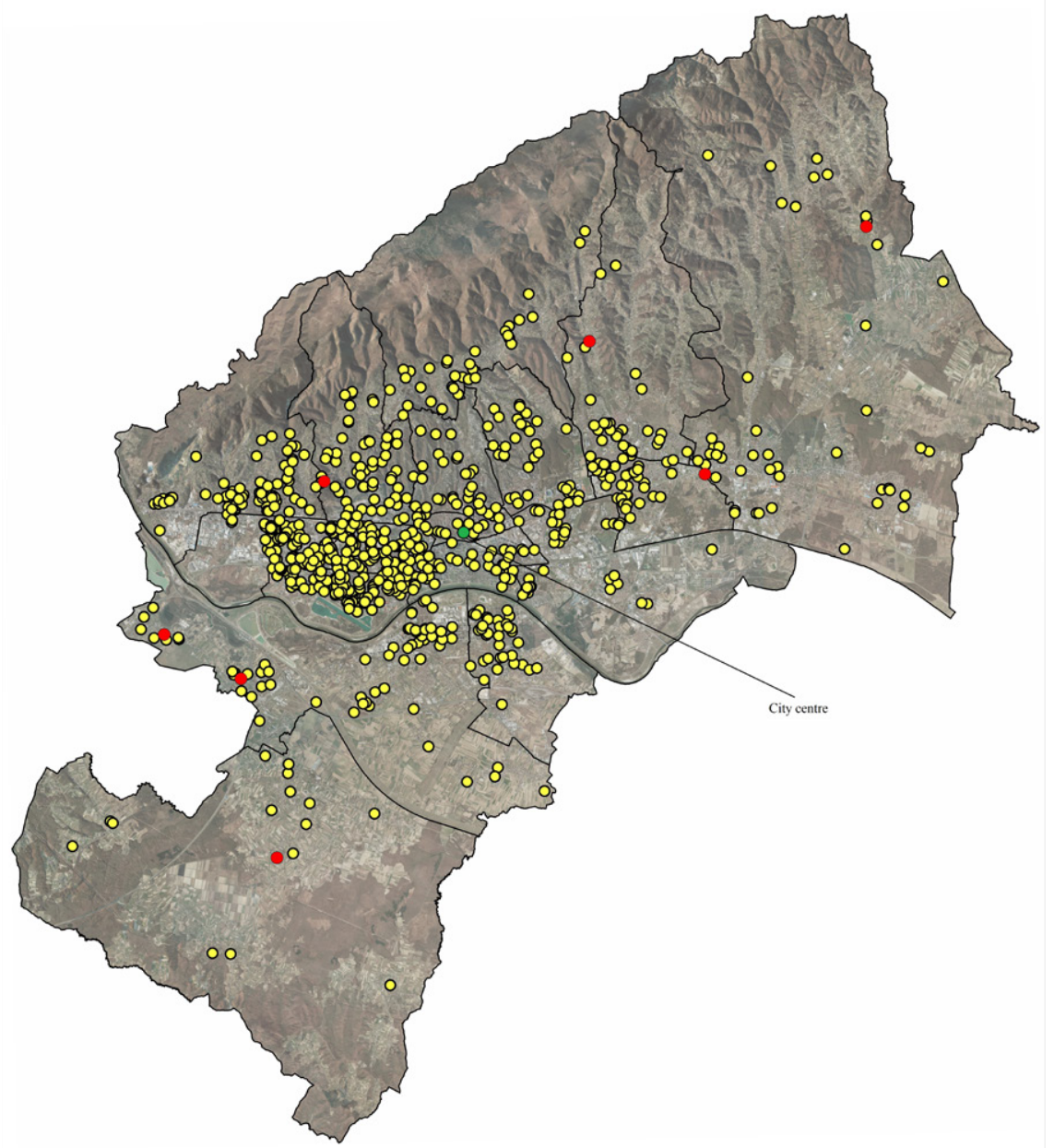

- Surveyed students not participating in evening outings outside their neighbourhood

O Surveyed students

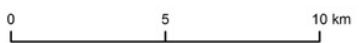

Fig. 1.

Spatial Distribution of High School Students Unable to Attend Evening Outings Because of Transportation Source: Survey; Digital Orthophoto Layer, 2012 


\section{Conclusion}

The influence of transport disadvantage was to some extent present at the evening outings of students. Transport may affected access to evening outings. It can be concluded that travel time and transport mode to the locations of activity affected the accessibility of activity and, at the end, the engagement in the activity. Students who travelled longer to activity and used public transport or were driven by somebody else because they did not have the possibility to use public transport had more problems with evening outings. The problem was primarily manifested in the segment of returning home. Due to the low frequency of public transport at night or its lack, but also the avoidance of its use due to the safety reasons that occurred in a part of the student, high school students are forced to seek alternative solutions. This included early departure from the venue of the evening outing or use of taxi (which leads to additional costs) and transportation by parents and friends. There were more problems for students living in peripheral parts of the city.

Optimization of transport services in the context of improving the quality of transport is extremely important for alleviating the impact of transport disadvantage. Increasement of the operation frequency during night in public transport in some parts of the city (in addition to their previous detection) as well as increasement of security in vehicles, increasement of safety in taxis are just some of the possibilities for dealing with transport disadvantage. The whole process of reducing transport disadvantage is not possible without a multidisciplinary approach of various professions and institutions. In doing so, involvement of transport disadvantage in the spatial planning system and its incorporation into the legal framework of state social policy is needed. As the Croatian scientific bibliography lacks research concerning transport disadvantage, emphasis should be put on intensive implementation of various research within determining transport disadvantaged social groups and spaces they live in. Only systematic approach to this topic can raise the awareness of people about these kinds of inequity in society, and thereby detect possible measures to reduce transport disadvantage and social exclusion, as well as improving the quality of life, with the ultimate goal of achieving transport and social justice.

\section{References}

Bourn, R. 2013. No Entry! Transport Barriers facing Young People, Intergenerational Foundation. 37 p. Available from internet: <http://www.if.org.uk/wpcontent/uploads/2013/05/No_Entry_final_report_ definitive.pdf.>. Accessed: 09/04/2017.

Calafat, A.; Blay, N.; Juan, M.; Adrover, D.; Bellis, M.A.; Hughes, K.; Stocco, P.; Siamou, I.; Mendes, F.; Bohrn, K. 2009. Traffic Risk Behaviors at Nightlife: Drinking, Taking Drugs, Driving, and Use of Public Transport by Young People, Traffic Injury Prevention 10(2): 162-169.

Chatterton, P.; Hollands, R. 2003. Urban Nightscapes: Youth Cultures, Pleasure Spaces and Corporate Power. Psychology Press. 300 p.

Cohen, L.; Manion, L.; Morrison, K. 2007. Metode istraživanja u obrazovanju (Research Methods in Education; In Croatian). V. edition. Naklada Slap. Croatia. 464 p. 
Council for children of the Government of the Republic of Croatia and National institute for protection of family, maternity and youth. 2003. Etički kodeks istraživanja s djecom (Code of Ethics of Research with Children; In Croatian). Available from Internet: <http://www.dijete.hr/en/documents/ doc_view/232-etiki-kodeks-istraivanja-s-djecom. raw?tmpl=component $>$.

Cullinane, S.; Stokes, G. 1998. Rural Transport Policy. Pergamon. Netherlands. 352 p.

Currie, G.; Stanley, J. 2007. Young Australians: No Way to Go. In: No Way To Go - Transport and Social Disadvantage in Australian Communities (ed. Currie, G.; Stanley, J.; Stanley, J.). Monash University ePress. Australia. 08.1-08.14.

Currie, G.; Delbosc, A.; Mahmoud, S. 2013. Factors Influencing Young Peoples' Perceptions of Personal Safety on Public Transport, Journal of Public Transportation 16(1): 1-19.

Currie, G.; Gammie, F.; Waingold, C.; Paterson, D.; Vandersar, D. 2005: Rural and regional young people and transport. Improving access to transport for young people in rural and regional Australia. National Youth Affairs Research Scheme. 85 p. Available from internet: <https://docs.education.gov.au/system/files/ doc/other/rural_and_regional_young_people_and_ transport.pdf. $>$ Accessed 10/04/2017.

Dodson, J.; Gleeson, B.; Sipe, N. 2004. Transport Disadvantage and Social Status: a review of literature and methods. Australia: Urban Policy Program, Griffith University. 63 p.

DOF. 2012. Digital ortophoto 2012. Geoportal of Zagreb infrastructure of spatial data. City of Zagreb. Croatia.
Duff, C.; Moore, D. 2015. Going out, getting about: atmospheres of mobility in Melbourne's night-time economy, Social \& Cultural Geography 16(3): 299-314.

Fyhri, A.; Hjorthol, R. 2009. Children's independent mobility to school, friends and leisure activities, Journal of Transport Geography 17(5): 377-384.

Gašparović, S. 2016. Theoretical postulates of transport disadvantage, Hrvatski geografski glasnik 78(1): 73-95.

Gašparović, S.; Jakovčić, M., 2014. Transport disadvantage: the example of high school population in the City of Zagreb, Geoadria 19(1): 61-99.

Hopkins, P.E., 2010. Young people, place and identity. Routledge. United Kingdom. 320 p.

Horton, J.; Kraftl, P.; Tucker, F. 2011. Spaces-in-themaking, childhoods-on-the-move. In: Children and Young People's Spaces (eds. Foley, P.; Leverett, S.). Palgrave Macmillan. United Kingdom. 240 p.

House of Commons, Environmental Audit Committee. 2013. Transport and accessibility to public service. Available from internet: <https://www. publications.parliament.uk/pa/cm201314/cmselect/ cmenvaud/201/201.pdf.>

Houwing, S.; Twisk, D. 2015. Nothing good ever happens after midnight: Observed exposure and alcohol use during weekend nights among young male drivers carrying passengers in a late licensing country, Accident Analysis \& Prevention 75: 61-68.

Hoyle, B.; Knowles, R. 1998. Transport geography: An introduction. In: Modern Transport Geography, Second revised edition (ed. Hoyle, B.; Knowles, R.). John Wiley \& Sons. United Kingdom. 1-12. 
Hurni, A. 2006. Transport and Social Disadvantage in Western Sydney: A Partnership Research Project. University of Western Sydney and Western Sydney Community Forum. Australia. 104 p.

Hurni, A. 2007. Marginalised groups in Western Sydney: The experience of sole parents and unemployed young people. In: No Way To Go - Transport and Social Disadvantage in Australian Communities (ed. Currie, G.; Stanley, J.; Stanley, J.). Monash University ePress. Australia. 10.1-10.11.

Murray, A.T.; Davis, R. 2001. Equity in regional service provision Journal of Regional Science 41 (1): 577-600.

Obiteljski zakon (Family Act; In Croatian), Narodne novine (Official Gazette) 116/03.

Rosier, K.; McDonald, M. 2011. The relationship between transport and disadvantage in Australia. Australian Institute of Family Studies. Australia. 10 p.

Scagnolari, S.; Walken, J.; Maggi, R. 2015. Young drivers' night-time mobility preferences and attitude toward alcohol consumption: A Hybrid Choice Model, Accident Analysis \& Prevention 83: 74-89.

Social Exclusion Unit, 2003. Making the Connections: Final Report on Transport and Social Exclusion. Office of the Deputy Prime Minister. United Kingdom. 145 p.

Stanley, J.; Stanley, J. 2004. Improving Public Transport to meet Comunity Needs: A Warrnambool Case-study. Bus Asociation Victoria and Warrnambool Bus Lines. Australia. 92 p.

Yigitcanlar, T.; Kushairi, R.; Dur, F. 2010. Sustainable Urban and Transport Development for Transportation Disadvantaged: A Review, The Open Transportation Journal 4: $1-8$. 